\title{
СУЧАСНІ НАУКОВІ ПІДХОДИ ДО ОЦІНЮВАННЯ ІНШОМОВНОЇ КОМПЕТЕНТНОСТІ СТУДЕНТІВ ПІД ЧАС ДИСТАНЦІЙНОГО НАВЧАННЯ
}

\author{
Бсловецька Л. Е. \\ кандидат педагогічних наук, \\ старший викладач кафедри іноземних мов та професійної комунікації \\ Східноукраїнський національний університет імені Володимира Даля \\ пр. Центральний, 59-А, Сєвєродонецьк, Луганська область, Україна \\ orcid.org/0000-0003-3360-687X \\ outstandingpointofview@gmail.com
}

\author{
Ключові слова: інструменти \\ оцінювання, іншомовна \\ компетенияія, дистанизійе \\ навчання.
}

\begin{abstract}
У статті висвітлено проблеми оцінювання іншомовної компетентності студентів вищих навчальних закладів; надано результати аналізу та характеристика основних інструментів для об'єктивного оцінювання рівня володіння англійською мовою студентами закладів вищої освіти. Сьогодні науковий та технічний прогрес вимагає впровадження нових сучасних технологій у всіх сферах, включаючи освіту. Для визначення ефективності оцінювання рівня знань студентів 3 іноземних мов охарактеризовано такі інструменти для дистанційного навчання, як Google forms, Google Docs, Quizlet, Socrative, Kahoot, SurveyMonkey, PollEverywhere, Screencast-o-matic, TrainingCheck, CloudApp, Dropbox, Weebly, що дають змогу перевіряти засвоєний студентами матеріал новими і творчими способами. Ці інструменти є зручними у процесах викладання англійської мови та навчання мові, оскільки забезпечують такі функції: викладачеві - зручну швидку перевірку рівня володіння студентом англійською мовою, можливість переглянути типові помилки та обговорити їх зі студентами для корегування їхнього подальшого плану навчання, можливість підвищити рівень викладання іноземної мови. 3'ясовано, що використання онлайн-інструментів для контролю знань викладачем та самостійного оцінювання рівня володіння англійською мовою студентами забезпечує вдосконалення їхніх знань з граматики $\mathrm{i}$ лексики, покращення навичок володіння письмом, та надає студентам можливість відчути швидкий зворотній зв'язок, що позитивно впливає на їхню мотивацію виконувати онлайн-завдання та вивчати іноземну мову, допомагає підтримувати самонавчання. Поєднання застосування згаданих засобів у викладанні іноземної мови 3 використанням сучасних інформаційних технологій - це один із шляхів підвищення мотивації студентів. Основна увага в навчальному процесі приділяється підвищенню активності студентів та використанню підходів та сучасних інструментів навчання, що підвищують активність на занятті. В умовах глобалізації викладачі іноземних мов постійно відчувають необхідність удосконалення вмінь i навичок роботи 3 інтернет-інструментами, застосування яких позитивно впливає на якість навчання та розвиток іншомовної компетентності студентів у закладах вищої освіти.
\end{abstract}




\title{
MODERN SCIENTIFIC APPROACHES TO EVALUATING STUDENTS' FOREIGN LANGUAGE COMPETENCE DURING DISTANCE LEARNING
}

\author{
Bielovetska L. E. \\ PhD in Pedagogy, \\ Senior Lecturer at the Department of Foreign Languages and Professional Communication \\ Volodymyr Dahl East Ukrainian National University \\ Tsentralnyi avenue, 59-a, Sievierodonetsk, Luhansk region, Ukraine \\ orcid.org/0000-0003-3360-687X \\ outstandingpointofview@gmail.com
}

Key words: assessment tools, foreign language competence, distance learning.
The article highlights the problems of formation and assessment of students' foreign language competence at higher educational institutions. Today, scientific and technological progress requires the introduction of new modern technologies in all areas, including education.

Such distance learning tools as Google forms, Google Docs, Quizlet, Socrative, Kahoot, SurveyMonkey, PollEverywhere, Screencast-o-matic, TrainingCheck, CloudApp, Dropbox, Weebly allow to check the material mastered by students in new and creative ways and determine the effectiveness of assessing students' proficiency in foreign languages. These tools are convenient for teaching English and language learning, as they provide the following functions: for teacher - a convenient quick check of the students` English proficiency, the ability to review common mistakes and discuss them with students, to adjust their further study plan, to improve foreign language teaching.

It was found that the use of online tools for teacher control and self-assessment of English proficiency improves students' knowledge of grammar and vocabulary, improves writing skills, and gives students the opportunity to experience quick feedback, which has a positive effect on their motivation to do online-exercises and learn a foreign language, helps to support self-study. The combination of the use of mentioned means in teaching a foreign language using modern information technologies is one of the ways to increase student motivation. Creation of special programs for the formation of linguistic competencies in the framework of professional direction, the use of the Internet in the educational process will help to motivate students in studing foreign languages. The main focus in the educational process is to increase the activity of the learner and the use of methods and modern teaching aids that increase the activity in the classroom. In the conditions of globalization, teachers of foreign languages need to improve internet skills, the use of which positively affects the quality of training and the development of foreign language competence in higher education institutions.
Постановка проблеми. Оцінювання $\epsilon$ невід'ємною частиною викладання, незалежно від того, відбувається це віч-на-віч чи дистанційно. Оцінювання - це збір інформації про те, що наші студенти знають і можуть зробити, щоби ми могли вжити принципових дій під час викладання та зрозуміти, наскільки успішно вони пройшли курс навчання. Однак рішення, як найкраще оцінити студентів, може бути складним, особливо коли ми й наші студенти працюємо віддалено, пристосовуючись до незнайомого навчального середовища та використовуючи нові технології.
У статті ми розглянемо відповідні інструменти онлайн-оцінювання для студентів. Ми опираємося на підходи підсумкового оцінювання, яке має на меті показати, чого досягли студенти, оцінювання, яке зосереджується на моніторингу прогресу студентів як способу підтримки їхнього навчання. Основні принципи оцінки однакові в будь-якому контексті, й оцінювання дистанційно часто є питанням адаптації звичного оцінювання. Тим не менше, перехід до викладання онлайн може також стати можливістю критично та творчо подумати про те, як оцінити студентів та дослі- 
дити нові цифрові інструменти та підходи, які можуть дати глибше розуміння їхнього навчання. В умовах глобалізації викладачі іноземних мов постійно відчувають необхідність удосконалення вмінь і навичок роботи з інтернет-інструментами, застосування яких позитивно впливає на якість навчання та розвиток іншомовної компетентності студентів у закладах вищої освіти.

Аналіз останніх досліджень і публікацій. Проблеми формування та оцінювання іншомовної компетентності студентів вищих навчальних закладів розглядались у роботах вітчизняних дослідників Д. Демченко, О. Нітенко, С. Опрятного, О. Хоменко, О. Чаюк та ін., зарубіжних учених S. Brown, J. Cowan, K. Gamage, S. Hedge, A. Paramour, P. Race, B. Smith та ін. Науковці зазначають, що використання онлайн-технологій для контролю знань та самостійного оцінювання володіння англійською мовою студентами забезпечує вдосконалення їхніх знань із граматики й лексики, покращення навичок володіння письмом та надає студентам можливість відчути швидкий зворотній зв'язок, що позитивно впливає на їхню мотивацію вивчати іноземну мову, допомагає організувати дистанційне навчання.

Питання само- і взаємоконтролю рівня сформованості англомовної компетентності у майбутніх спеціалістів 3 використанням інформаційних технологій впродовж тривалого часу розглядалося у працях провідних методистів, педагогів та психологів, таких як І.О. Зимняя, А.В. Конишева, О.В. Мусницька, С.Ю. Ніколаєва, О.О. Миролюбов, Ю.І. Пассов, Н.Ф. Тализіна, В.С. Цетлін та інші. Огляд сучасних публікацій свідчить про те, що актуальною $\epsilon$ проблема методики контролю сформованості іншомовної комунікативної компетентності та iï окремих складників у процесі вивчення мови.

Огляд сучасних публікацій свідчить про те, що актуальною є проблема методики контролю сформованості іншомовної комунікативної компетент-

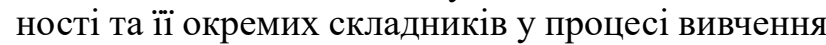
мови. Я.А. Крапчатова досліджувала проблему організації само- і взаємоконтролю сформованості англомовної компетентності в аудіюванні, І.Ф. Мусаелян висвітлювала методику формування та контролю лексико-граматичного компонента мовної компетентності, В.В. Осідак розглядала проблему комплексного контролю сформованості англомовної граматичної компетентності, С.I. Шукліна розробляла методику контролю сформованості англомовної соціокультурної компетентності. Окремі аспекти проблеми тестового контролю розкриваються у дослідженнях О.А. Гришиної, А.В. Дроздової, О.Г. Квасової, О.В. Кміть, А.В. Матієнко, Р.П. Мільруд, О.О. Молокович, О.П. Петращук, Н.С. Саєнко,
О.О. Української та інших. Самооцінюванню і взаємоконтролю рівня сформованості англомовної компетентності присвятили свої роботи ряд зарубіжних учених: Г. Андраде, П. Бланш, Д. Боуд, А. Вальтчева, А. Грей, Б. Зіммерман, Б. Меріно, М. Оскарсон, М. Пуустінен, Л. Пулккінен, Дж. Росс, Н. Фальчиков.

Актуальність поставленої проблеми поглиблюється суперечностями між потребою у викладанні іноземних мов у вищих навчальних закладах під час дистанційного навчання, потребою формування іншомовної комунікативної компетентності студентів та недосконалістю науково-методичного забезпечення для онлайн-оцінювання.

Мета статті полягає у визначенні підходів для оцінювання іншомовної компетентності студентів онлайн, їхніх аналізу та характеристики.

Виклад основного матеріалу. Важливої ролі набуває оцінювання іншомовної компетентності студентів закладів вищої освіти згідно зі світовими стандартами володіння іноземними мовами, зокрема, англійською як іноземною. 3 цього приводу однією з актуальних форм такого оцінювання $є$ онлайн-формат. Це пояснюється його впливом на мотивацію студентів проходити онлайн-тести через швидкий зворотній зв'язок та максимальне об'єктивне оцінювання результатів, що дає змогу викладачу значно скоротити витрати часу на здійснення контролю і позбавити його трудомісткої роботи під час обробки результатів. До неформального оцінювання належить перевірка домашнього завдання, вікторини, нестандартні завдання, спостереження. Формувальне оцінювання полягає в тому, що викладач дає студентам змогу долучитися до навчання. Тому, викладачі мають відповідально навчати та допомагати студентам оцінити свій прогрес. Підсумкове оцінювання полягає в оцінюванні того, чи виконані завдання. Формальне оцінювання може бути проведено у вигляді підсумкового контролю знань, стандартизованих тестів. Викладачі краще за всіх знають своїх студентів, рівень їх знань, та доступні ресурси для них.

Використання комп'ютерних технологій можна спрямувати не лише на контроль знань студентів, але й на їх поглиблення. Створення спеціальних програм для формування у студентів мовної компетенції в рамках професійного спрямування, використання мережі інтернет у навчальному процесі, розробка проєктів, презентацій з використанням комп'ютерних технологій та інтернет-ресурсів допоможе мотивувати та зацікавлювати студентів у вивченні іноземних мов. Поєднання застосування згаданих засобів у викладанні іноземної мови 3 використанням сучасних інформаційних технологій - це один із шляхів підвищення мотивації студентів, адже 
для сучасної людини оволодіння навичками користування комп'ютером, пошуку необхідної інформації в інтернеті є невід'ємними чинниками професійної самореалізації. Обговорення підготовленого студентом матеріалу 3 використанням мережі інтернет, дискусії, рольові ігри сприятимуть ефективному формуванню навичок монологічного та діалогічного мовлення.

Студенти можуть не мати постійного доступу до електронного пристрою або надійного 3'єднання з інтернетом, і це потрібно врахувати у плануванні оцінювання. Якщо студенти стикаються i3 цими цифровими обмеженнями, можна обрати методи оцінювання, які передбачають асинхронну роботу (тобто гнучко, у власний час студентів) i, можливо, офлайн або на папері.

Якщо мета викладача не оцінювати цифрові навички своїх студентів, важливо мінімізувати їхній вплив на мовне оцінювання. Одним із головних завдань викладача $\epsilon$ ознайомлення студентів 3 інструментами та платформами, включивши їх у свої навчальні програми. Перед будь-яким онлайн-оцінюванням слід надати студентам чіткі інструкції та достатню практику, особливо якщо вони працюватимуть за таймером.

Студенти можуть відчувати особливе занепокоєння під час оцінювання, коли вони працюють віддалено. Тому викладачеві слід переконатися, що студенти розуміють, що й чому оцінюється і що вони мають можливість ставити питання як приватно, так і публічно. Викладачеві необхідно продумати як найкраще допомогти студентам досягти успіху. Адже якщо вони відчуватимуть тривожність під час тестування, то це негативно вплине на їхнє самопочуття або результати. Ви можете розглянути методи оцінювання, які передбачають менший тиск, такі як тести чи електронні портфоліо.

Важко було б повністю виключити ризик списування за певних умов, але важче відстежувати студентів, які працюють віддалено. Є можливість контролювати офіційні тести в інтернеті через вебкамери, але може бути більш конструктивним вирішення спокуси студентів обдурити шляхом побудови довіри. Один із підходів полягає в тому, щоби допомогти їм - i їхнім батькам - зрозуміти, як оцінка приносить користь навчанню й чому результати повинні точно відображати їхні здібності. Ви також можете запровадити «кодекс честі», попросивши студентів підписати заяву, щоби підтвердити, що робота є повністю їхньою. Студент, який має низьку академічну грамотність, може бути легко сприйнятий як нечесний студент. Прийнято вважати, що плагіат викликаний недостатнім знайомством із плагіатом загалом, а також через недостатню обізнаність із програмним забезпеченням для виявлення плагіату. Згідно
3 особистим досвідом, студенти не мають наміру плагіатувати, але вони дуже часто не знають посилань. Оскільки так багато доступних програм, вебсайтів та платформ, вибір може здатися надзвичайним. Зазвичай рекомендується визначитися що потрібно оцінити та визначити обмеження, 3 якими можливо стикнетесь, оскільки це значно звузить варіанти. Немає необхідності використовувати широкий спектр цифрових інструментів та ресурсів, якщо інструмент чи ресурс добре працює для вас та ваших студентів, продовжуйте використовувати його.

Щоби ефективно керувати навчанням, важливо знати, що студенти розуміють і вміють робити. Однак збір цих доказів - процес, який називається формативним оцінюванням - може бути важким, коли викладач переходить від особистого до онлайн-викладання, i більше не може спостерігати, контролювати та взаємодіяти зі своїми студентами. Технологія може допомогти відтворити деякі умови фізичного кабінету. Він також пропонує альтернативні канали участі студентів, такі як чат та демонстрація екрану, дошки, які варто навчитися використовувати [5].

Підготовка студентів до офіційного тестування особливо важлива, коли викладач не можете бути особисто там, щоби надати підтримку під час самого тестування. Перед тестом слід приділити час, ознайомлюючи студентів із форматом тесту, переконавшись, що вони знають, що він оцінить i чому. Викладач має переконатися, що студенти розуміють правила і можна надати широкі можливості для практики з використанням цифрових інструментів.

Безпека тестування в інтернеті, зрозуміло, є широко поширеною проблемою. Неможливо повністю усунути ризик обману, можна використовувати вебкамери, щоби контролювати студентів під час тесту. Викладач не може побачити реакцію студентів, їхні обличчя, коментарі й емоційний стан студента під час отримання та виконання завдання.

Доцільно було б попросити тримати телефони у видимому місці на екрані, щоби викладач міг побачити, що вони вимкнені. Зосередження довірі може допомогти студентам зрозуміти, як оцінка приносить користь їх навчанню. Важливо бути дуже обережним щодо рішень, прийнятих на основі результатів тестування, особливо коли ви не маєте повного контролю над безпекою тесту. Поєднання результатів тесту з інформацією 3 інших джерел, наприклад, електронних портфоліо чи проєктів, може запропонувати більш широке уявлення про здібності учнів.

Дж. Кован зазначає, що оцінка не має передбачати формальних тестів і варто розглянути альтернативні підходи до підсумкового оцінювання, які можуть бути спрямовані на ширший спектр 
навичок, чинити менший тиск на студентів та краще відображати автентичне використання мови. Викладаючи дистанційно, відстеження прогресу мовних навичок може здатися складним, але можливим. Це полегшить оцінку в довгостроковій перспективі. Слід пам'ятати про важливість побудови довіри та автономії у наших студентів. Дистанційне оцінювання - це ще одна можливість розвинути ці критичні навички навчання [5].

Iз будь-якою новою системою на початку потрібно виконати певне планування та підготовку. Викладачеві слід визначитися що саме збирається оцінити, як під час заняття, так і для виконання домашнього завдання та іншого доручення. Доцільно також включити нетрадиційні форми оцінювання, такі як участь, творчість. Використання опитувань та вікторин - це корисний спосіб оцінити студентів, не витрачаючи багато часу на перевірку та оцінювання. Використання онлайн-опитування або вікторини також може бути анонімним, що може спонукати менш впевнених студентів брати участь у виконанні цього завдання. Отже, умовами успішного навчання іноземної мови $\epsilon$ контроль за виконанням усіх дій, що є складовими відповідної діяльності, увага до всіх внутрішніх і зовнішніх механізмів іi реалізаціі, удосконалення операційного аспекту, глибокий аналіз спонукально-мотиваційних чинників. Із метою оптимізації формування іншомовної комунікативної компетентності варто впроваджувати певні інструменти:

- Google Forms - можна використовувати для true/false, завдань із множинним вибором, відкритими відповідями, короткими відповідями. Викладач самостійно може створити шкалу, встановити, яка відповідь правильна, щоб комп'ютер робив усі позначення, завантажувати фотографії, відео, аудіо чи текст та ставити запитання.

- SurveyMonkey - ще один сайт із подібними функціями. Безоплатна версія дає змогу скласти до десяти питань.

- Quizlet - це інтернет-інструмент для складання вікторин за допомогою зображень або слів. Його часто використовують для створення флешкарток або цікавих вікторин. Ці вікторини можна використовувати для домашнього завдання або на уроці.

- Kahoot - цей інструмент допомагає створювати вікторини, які можна відтворювати на певних пристроях або в команді.

- Socrative дає змогу створювати живі вікторини, і це може бути цікавим способом для студентів продемонструвати, чого вони навчились. Крім того, вони можуть відповідати на запитання за допомогою жестів руками або піднімати аркуші паперу 3 написаними на них відповідями. Якщо регулярно використовувати кілька платформ, можна зберігати запитання в окремій електронній таблиці, щоби полегшити їх пошук і повторне використання в майбутньому.

Групові проєкти можуть мати різну форму - від презентацій та плакатів до листівок та вебсайтів. Вони дають змогу оцінювати глобальні навички, такі як співпраця та цифрова грамотність, поряд із мовою, а виявлення індивідуальних внесків студентів стає простішим, коли вони співпрацюють у цифровій формі. Інтернет-інструменти для створення авторів, такі як Google Docs, дають змогу відстежувати редагування, зроблені кожним студентом, тоді як програми для спільної роботи, такі як Slack, записують їхню співпрацю, коли вони працюють разом.

GoogleDocs (частина GoogleDrive) - це набір хмарних програм для спільної роботи, що включають текстовий процесор, редактор зображень, програмне забезпечення для електронних таблиць та презентацій та платформу опитування. Документ схожий на інтерфейс Microsoft Word, але він має кілька захоплюючих інших функцій. Найважливішою особливістю GoogleDocs $€$ те, як студенти можуть співпрацювати над одним документом у режимі реального часу. GoogleDocs має функцію для коментування тексту, а також вікно чату зліва на екрані. Документи можна створювати безпосередньо у браузері або завантажувати 3 комп'ютера. Уся робота в документі автоматично зберігається в хмарному сховищі, тому ви можете повертатися до того самого документа багато разів не турбуючись про втрату своєї роботи [9].

Електронні портфоліо, як і паперові портфоліо, об'єднують зразки робіт студентів із рефлексивними коментарями та сприяють розвитку автономії, саморефлексії та навичок критичного мислення. Електронні портфоліо надають додаткові переваги, оскільки вони можуть включати аудіо та відеофайли, легко ділитися з колегами та розвивати цифрову грамотність. Студенти можуть створювати електронні портфоліо за допомогою інструментів для створення блогів або вебсайтів, таких як Weebly або WordPress. Як низькотехнологічний варіант, студенти можуть працювати на папері, а потім сканувати та завантажувати свої роботи.

Для того щоби оцінити мовлення, ви можете попросити студентів зробити аудіо чи відеозаписи, працюючи індивідуально, в парах або в групах. Ці записи можуть мати різні формати, такі як презентації чи коментарі на малюнку чи графіку, i вони забезпечують хорошу можливість для самооцінки та оцінки за допомогою дескрипторів CEFR aбо інших критеріїв оцінки. Студенти мають змогу створювати та ділитися своїми записами за допомогою спеціальних інструментів, таких як Screencast-o-matic або CloudApp, або вони могли завантажувати записи смартфонів у службу обміну файлами, як Google Drive або Dropbox. 
Ідеї та роздуми студентів також можна збирати асинхронно після уроку. Наприклад, студенти могли взяти участь в опитуванні через веб-сайт / додаток, як Poll Everywhere; ви можете створити для них вікторину за допомогою інструмента для створення вікторин, такого як Google Forms; або студенти могли сприяти дискусійному форуму, який можна створити на багатьох навчальних платформах та системах управління навчанням (Moodle). Незалежно від того, чи оцінювання відбувається в інтернеті чи віч-на-віч, мета одна: визначити метод, який є точним і справедливим, репрезентативним для реального використання мови, корисним для навчання студентів та практичним для впровадження. Будь-який обраний метод буде специфічним для конкретної ситуації, визначається часом та ресурсами, які у вас $\epsilon$, i може передбачати певний компроміс.

Висновки та перспективи подальших досліджень. Дистанційне навчання, пройшовши ста- дію експериментального випробування, сьогодні стає рівноправною формою освіти поряд із денною формою навчання. При цьому воно $є$ перспективним $з$ огляду на посилення тенденції навчання протягом усього життя, $\epsilon$ економічно вигідним для навчальних закладів тощо. За таких умов особливого значення набуває якість навчального середовища та забезпечення сучасних підходів до оцінювання іншомовної компетентності. У статті було окреслено основні інструменти для оцінювання та узагальнено інформацію щодо ефективного впровадження різноманітних інструментів для оцінювання: Google forms, Quizlet, Socrative, Kahoot, SurveyMonkey, PollEverywhere, Slack, Screencast-omatic та ін. Перспективами подальших досліджень $\epsilon$ впровадження онлайн-додатків в освітній процес ЗВО для проведення оцінювання рівня володіння англійською мовою та аналіз впливу цих інструментів на рівень іншомовної компетентності студентів під час дистанційного навчання.

\section{ЛITEPATУРA}

1. Brown, S. and Race, P. (2012). Using Effective Assessment to Promote Learning, in University Teaching in Focus: a learning-centred approach, Hunt, L and Chalmers, D (eds), Australian Council for Educational Research and Routledge, (pp.74-91.) [in English].

2. Bretag, T. (2016). Discipline-specific approaches to academic integrity: Introduction. In Handbook of Academic Integrity, 1st ed.; Bretag, T., Ed.; Springer Science + Business Media Singapore Pte Ltd.: Singapore, (pp. 673-675) [in English].

3. Brimble, M. (2016). Why students cheat: An Exploration of the motivators of student academic dishonesty in higher education. In Handbook of Academic Integrity, 1st ed.; Bretag, T., Ed.; Springer Science + Business Media Singapore Pte Ltd.: Singapore. (pp. 365-380) [in English].

4. British Council: Assessing Learners Online: Noticing, Self-checking and Online Quiz Tools URL : https:// www.teachingenglish.org.uk/sites/teacheng/files/ Assessing-learners-online_noticing-self-checking-onlinequiz-tools.pdf [in English].

5. Cowan, J. (2005). Designing assessment to enhance student learning. URL : http://www.heacademy. ac.uk/assets/ps/documents/practice_guides/practice_guides/ps0069_designing_assessment_to_improve_ physical_sciences_learning_march_2009.pdf [in English].

6. Creating an Online Community, Class or Conference - Quick Tech Guide / Google Docs. 2020. URL:https://docs.google.com/document/u/0/d/1ux31TnUTpzZRuvxE3rAsSQ4Ihub96S8_OYECNh8wv-A/ mobilebasic\#heading=h.xpjunkqt5jka [in English].

7. Effective Assessment in a Digital Age: A guide to technology-enhanced assessment and feedback. URL : http://www.jisc.ac.uk/media/documents/programmes/elearning/digiassass_eada.pdf [in English].

8. Gamage, K. A. A., de Silva, E. K., \& Gunawardhana, N. (2020). Online delivery and assessment during COVID-19: Safeguarding academic integrity. Education Sciences, 10(11). URL : https://doi.org/10.3390/ educsci10110301 [in English].

9. Hedge, S. Teaching with GoogleDocs / A Blog from GradHacker and MATRIX: The Center for Humane Arts, Letters and Social Sciences Online. Washington, D.C., 2013. URL : https://www.insidehighered. $\mathrm{com} /$ blogs/gradhacker/teaching-googledocs [in English].

10. Pinto-Llorente, A. M., Sánchez-Gómez, M. C., García-Peñalvo. F. J., Casillas Martín. The use of online quizzes for continuous assessment and self-assessment of second-language learners». In F. J. GarcíaPeñalvo (Ed.), Proceedings of the Fourth International Conference on Technological Ecosystems for Enhancing Multiculturality (TEEM'16) (Salamanca, Spain, November 2-4, 2016) (pp. 819-824.) NewYork, NY, USA: ACM. URL : https://doi.org/10.1145/3012430.3012612 [in English].

11. Quality Assurance Agency. Contracting to Cheat in Higher Education: How to Address Contract Cheating, the Use of Third-Party Services and Essay Mills. 2017. URL : www.qaa.ac.uk.docs/qaa/guidance/ contracting-to-cheat-in-higher-education-2nd-edition.pdf [in English].

12. Tech Against Coronavirus. URL : https://techagainstcoronavirus.com [in English]. 